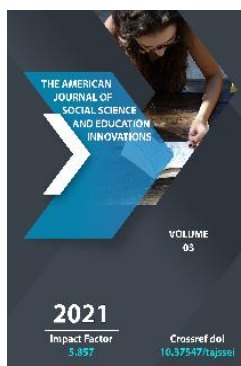

\title{
The History Of Irrigated Agriculture In The Jizzakh Oasis
}

\author{
Ahrorqul Hasanovich Pardaev \\ Candidate Of Historical Sciences, JSPI, Uzbekistan
}

Journal Website:

http://theamericanjour

nals.com/index.php/taj

ssei

Copyright: Original content from this work may be used under the terms of the creative commons attributes 4.0 licence.

\section{ABSTRACT}

This article studies irrigated agriculture in the Jizzakh oasis based on written and archaeological sources. The irrigation system of the Jizzakh oasis of the XVI-XIX centuries, the terms associated with irrigation, the agricultural oases formed during this period have been scientifically studied.

\section{KEYWORDS}

Archaeological research, written sources, Ustrushona, irrigated agriculture, irrigation structures, Kaliyatepa irrigation system, Orda irrigation system.

\section{INTRODUCTION}

According to archeological research and written sources, irrigated agriculture, which appeared in Ustrushan in ancient times, developed in later periods, and agriculture based on artificial irrigation systems developed in the country. Under the influence 
of political and demographic processes that took place in the early Middle Ages, the process of settlement of nomadic tribes in the territory of Ustrushona intensified. As a result, new rural areas and irrigated agricultural oases were formed around the cities of Ustrushona.

\section{THE MAIN RESULTS AND FINDINGS}

Along with archeological research on the developed and late medieval irrigated agriculture and irrigation system of the Jizzakh oasis, there is information in written sources. In particular, according to medieval geographers-tourists, during this period Ustrushona became a developed, diversified agricultural region of Movarounnahr, such as Sogd, Fergana, Shosh regions. The Arab historian Istahri described these regions as "there are no cities, villages, crops and pastures without water. They have the purest, the softest, the sweetest water. An unnamed author of Hudud al-Alam describes Jizzakh as a "city near running water." From these data it is possible to know that in the Middle Ages in Ustrushona, especially in its north-western rusts, in the present-day Jizzakh oasis, there were extensive irrigation systems, highly developed irrigated agriculture.

During the reign of Amir Temur and the Temurids, special attention was paid to the agriculture of the north-western Ustrushona, including the Jizzakh oasis. The irrigation system of the oasis was restored and agriculture flourished. The cities of Qaliyatepa and Orda were rebuilt, and the surrounding lands were used for agriculture, horticulture, and other purposes. As the Jizzakh oasis has long served as an "eastern gateway" of strategic importance to Samarkand Sogdiana,
Jizzakh soon regained its former position in the country's political and economic life.

During the reign of the Shaybanids in the 16th century, the Jizzakh oasis, in particular, a large administrative center from the Horde, which was its main city at that time, was used as a convenient military base. Due to the Sheibanikhan march, a large part of the Uzbek tribes from Dashti-Kipchak settled in the Jizzakh oasis, the population demographics increased sharply, as a result of which the need for new arable lands and water supply increased.

As a result, during the reign of Bukhara khan Abdullah II (1557-1598), the agricultural water supply of the Jizzakh oasis was $97 \mathrm{~km}$ from the Ravotkhoja dam in Zarafshan which was greatly improved by the construction of the Tuyatortar river. The water of the Tuyatortar canal was discharged into Sangzor and distributed to the makhallas (neighborhood )through 12 ditches called Jizzakh districts from 2 water separators in the territory of Jizzakh city. The canals of Kotarma, Ravalliq, Takchilik, Qaliya, Qangli, Khayrabad, Iran originate from the Khayrabad watershed of Sangzor, and the agricultural lands in the southern, eastern and partly western parts of Jizzakh are supplied with water. The canals of Jizzakh, Mulkanlik, Naiman, Saralik and Tashkent are $1.5 \mathrm{~km}$ from the abovementioned watershed. The headwaters were from the Beshquur watershed and were used to supply water to crops in the central, northern and western parts of Jizzakh. Since water scarcity is a major problem in the Jizzakh oasis, water distribution has long been a concern. For this purpose, positions such as "mirab", "amin", "aksakal”, “water guard" were established, and a specific management system of water management was 
established. Farmers have allocated a certain amount of man power and funds each year to repair dams, dig ditches and clear mud, according to the instructions of the water administrators. This work was carried out mainly on warm days of winter and early spring. The following facilities were used for water distribution:

Dam is the main dam that connects water from Sangzor. This structure was built on the riverbed by means of branches, grass, stones, and its water was blocked. To do this, a large amount of building materials, man power, horse-drawn carriages were required.

Dargat - a dam built at the head of the ditches. In most cases it is a special device made of wood. An irrigation structure that is installed in a narrower part of the head canal, the side of which is covered with grass, which distributes water to the canals. Dargat is called "varq" in Zarafshan oasis.

Band - Connecting ditches to distribute busy water to the piles. These ditches are called 'grass band' if they are connected to the lawn, and 'board band' if they are connected to the wood.

Kunda- A water separation structure installed in large canals that divide the water on a daily basis. The Kunda is called "tosin" in the Fergana valley, "labigardon", and "sediment" in Uratepa. The waterworks were built under the leadership of the mirabs.

In the Jizzakh oasis, "mirablik" is a very responsible position, which has been established by honest and fair people who have gained a great reputation in the country. The career has been passed down from generation to generation. Kaliya Molkanlik the head of neighborhood was Hazratqul mirab's (1900-1990) father Ortiqvoy "aksakal", his father Obodi makhsum also worked as a mirab, Hazratqul aksakal's grandson, honored irrigator in Uzbekistan Hasanboy Pardaev (1932-2000) during the khanate period (XVIIIXIX centuries) it was divided into 18 days. That is, according to the accepted procedure, all the water of the river for the first three days was given to the population of Yukori Sangzor (now Bakhmal district), all the water for the second three days to the population of Yangikurgan (now Gallaorol district), then 12 days to the population of Jizzakh principality. The 12-day water supply to the Jizzakh oasis was divided into 12 ditches. In turn, the water from the canals was distributed to farmers according to a strict schedule. Neighboring farmers such as Qaliya-Mulkanlik, Kangli, Khayrabad, and Sokhli used the "jug" as a water clock. In current measurements, each jar was about 15 minutes long. This means that the water supplied to a ditch is 96 jugs per day, and 1152 jugs in a 12-day water distribution. If 50 farms were irrigated from the water of a particular ditch, that farm received water once in 18 days and its irrigation time was 3 hours and 45 minutes. If 100 farms were to receive water from the canal, the time would be halved to about 2 hours.

Residents of Jizzakh's Cholmolkanlik, Tashkent, Saraylik, Jizzakh, and Uratepalik makhallas (neighborhoods) used the "poy" method in water distribution. That is, the size of the land of the water-receiving farmer was measured in double count. A crop of wheat or barley is given about 1 "poy" of water. A "poy " -'double clock' is defined by the shade of a mosque or a tree. 
During this period, the total area of the Orda, the administrative center of the Jizzakh principality under the Bukhara Khanate, was about 100 hectares, and there were many makhallas (neighborhoods) in the Shahristan and Rabod parts of the city. The inhabitants of each neighborhood had arable lands, arable lands and orchards around the Orda. Jizzakh residents worked on farmland from early spring to late autumn. Only the winter months did they return to the Orda.

Qaliyatepa and Orda irrigation stations joined together during this period to form an integrated irrigation system. As a result of population growth, land shortages are beginning to be felt in two ancient agricultural areas, especially around Qaliyatepa. As a result, the northern regions of the oasis began to develop desert areas. Some of the members of the Molkent makhalla, who had been engaged in farming around Qaliyatepa since ancient times, had conquered the northern lands of the Orda and founded the Chol-Molkanlik village.

\section{CONCLUSION}

The above data show that the culture of irrigated agriculture in the Jizzakh oasis was formed in ancient times and developed in later periods, and in the last Middle Ages reached its peak of development. Sources say that all irrigated agricultural oasis are located in the basin of the Sangzor River, on the banks of large rivers such as Ravotsay and Saykhansay. In the late Middle Ages, the Shaybani rulers paid special attention to the development of agriculture based on artificial irrigation in the Jizzakh oasis. An example of this is the solution of the problem of water shortage in
Jizzakh and the development of desert areas as a result of the construction of the Tuyatortar canal by Abdullah II. During this period, the need for new land increased as a result of a sharp increase in the population of Orda, the administrative center of the Jizzakh oasis. As a result, the lands on the northern side of the Orda were developed and new neighborhoods were formed.

\section{REFERENCES}

1. Betger E.K. Excerpts from the book "Puti $\mathrm{i}$ strany" Abul-Kasyma ibn Xaukalya // Tr. SAGU, Archeology Sredney Azii. Vyp. P / „T., 1957, 17-22 p

2. Muhamadjanov A.R. History of irrigation of the Lower Zarafshan oasis (from ancient times to the beginning of the $X X$ century). T., «Fan», 1972. - 375 p.

3. Pardaev M.H., Suyunov S.S, Pardaev A.H. Emergence and stages of development of irrigated agriculture in northwestern Ustrushna. OMMT, 30th edition. Samarkand-1999, 226-237 p.

4. Pardaev M.H. Material and cultural ties of ancient Fergana and Ustrushna. // Fergana in ancient and medieval times. S. 1994, 68$69 \mathrm{p}$.

5. Pardaev A.H. From the history of irrigated agriculture in the Jizzakh oasis during the Central Asian khanates. // The problem of studying the ancient and medieval history of Ustrushna in the history of Uzbekistan. Guliston-2007. 15-18s.

6. Pardayev, A. (2020). JIZZAK IN WRITING SOURCES OF XV-XVI CENTURIES. Archive Nauchnyx Publication JSPI, 1 (51). excreted from

https://science.iedu.uz/index.php/archive_jspi/article/view/ 5045 
7. Pardayev, A. (2020). Orda is the administrative and economic center of the Jizzakh oasis. Archive Nauchnyx Publication JSPI, 11 (1). izvlecheno ot https://science.iedu.uz/index.php/archive _jspi/article/view/ 1170

8. Pardayev, A. (2020). URBANIZATION PROCESSES IN THE JIZZAKH OASIS DURING THE CENTRAL ASIAN KHANATES. Archive Nauchnyx Publication JSPI, 1 (4). excreted from

https://science.iedu.uz/index.php/archive jspi/article/view/ 399

9. Hasanboyev, T. (2020). FROM THE HISTORY OF MEDIEVAL CITY CULTURE OF JIZAK OAS. 134-138 bb. Archive Nauchnyx Publication JSPI, 1 (76). excreted from https://science.iedu.uz/index.php/archive_jspi/article/view/ 3002

10. Hasanboyev, T. (2020). Jizzakh oasis in the XIV-XVI centuries. Archive Nauchnyx Publication JSPI, 1 (78). excreted from https://science.iedu.uz/index.php/archive _jspi/article/view/ 3001

11. Adilov, J. K. (2019). THE CAMPAIGN OF ALEXANDER BEKOVICH-CHERKASSKY IN THE WORKS OF VV BARTHOLD. Theoretical \& Applied Science, (10), 572574.

12. Адилов, Ж. (2014). Экспедиция Александра Бековича-Черкасского в Среднюю Азию: историографическая динамика. O'zbekiston tarixi, (4), 47-61.

13. DAVLATOVA, K., \& NEMATOV, O. (2021). Tajiks of jizzakh oasis: traditional way of life, customs and traditions and rituals. Journal of Contemporary Issues in
Business and Government, 27(3), 13241329.

14. Odilov, B. A., \& Karimov, N. R. (2020). ANALYSIS OF TARGETED RESEARCH IN 2030 YEARS OF THE XX CENTURY. PalArch's Journal of Archaeology of Egypt/Egyptology, 17(6), 8887-8893. 